Western University Scholarship@Western

Centre for the Study of International Economic

Centre for the Study of International Economic

Relations Working Papers

Relations

1986

\title{
Licensing versus Direct Investment: A Model of Internalization by the Multinational Enterprise
}

Ignatius Horstmann

James R. Markusen

Follow this and additional works at: https://ir.lib.uwo.ca/economicscsier_wp

Part of the Economics Commons

Citation of this paper:

Horstmann, Ignatius, James R. Markusen. "Licensing versus Direct Investment: A Model of Internalization by the Multinational Enterprise." Centre for the Study of International Economic Relations Working Papers, 8611C. London, ON: Department of Economics, University of Western Ontario (1986). 
ISSN $\quad 0228-4235$

ISBN $0-7714-0746-7$

THE CENTRE FOR THE STUDY OF INTERNATIONAL ECONOMIC RELATIONS

WORKING PAPER NO. $8611 \mathrm{C}$

LICENSING VERSUS DIRECT INVESTMENT: A MODEL

OF INTERNALIZATION BY THE MULTINATIONAL ENTERPRISE

Ignatius Horstmann

and

James R. Markusen

This paper contains preliminary findings from research work still in progress and should not be quoted without prior approval of the authors.

DEPARTMENT OF ECONOMICS

THE UNIVERSITY OF WESTERN ONTARIO

LONDON, CANADA

N6A 5 C 2

Department of Econonics Library

JUL $8 \quad 1986$

University of Western Ontario 
LICENSING VERSUS DIRECT INVESTMENT: A MODEL

OF INTERNALIZATION BY THE MULTINATIONAL ENTERPRISE

\author{
Ignatius Horstmann \\ James R. Markusen \\ Department of Economics \\ University of Western Ontario \\ London Canada
}

March, 1986

Depantiben of Extromics libraty

JUL $8 \quad 1986$

Drinersizy of Western Ontario 
A firm must decide whether to serve a foreign market by exporting, building a foreign branch plant or licensing the production to an existing foreign producer. The existence of reputations implies that any licensing agreement must provide a licensee with the incentive to maintain the reputation. This creates a motive for the firm to internalize transactions by building a branch plant (i.e. by becoming a multinational). The model reflects a more general notion that the inability of the firm to control a licensee's (agent's) actions can provide incentives for multinational activity. The paper explores the determinants of the firm's mode of operation as well as exploring the consequences of certain government policies. 


\section{INTRODUCTION}

Starting with early studies by Dunning (1958) and Hymer (1960), economists have investigated the pattern of production by multinational enterprises (MNE's) in an attempt to uncover the factors contributing to their development. (For recent reviews of this literature see Caves (1982), Rugman (1985) and Casson (1985).) A consistent theme in this literature is that foreign direct investment (FDI) by multinationals results from the existence of some "special firm asset" the return on which cannot be fully realized through a licensing agreement. Because of this incomplete appropriability, the MNE transfers the asset internally though the establishment of a branch plant. Thus, for instance, should a firm possess proprietary information on a production technology, it may choose to transfer the technology (and the information) internally through FDI rather than risk having the information become public due to a licensing agreement. This explanation for MNE's has come to be known as the internalization hypothesis.

Perhaps because this internalization notion seems to lend itself to analysis little more sophisticated than the above sort of example, models of MNE activity tend to overlook this issue. Invariably, multinationals are either assumed to exist (as in Markusen (1984) and Helpman (1984)) or, where the FDI decision is modeled, to be unable to license the special asset (so that the choice is between FDI and exporting only. See Horstmann and Markusen (1986).). Ethier (1986) raises the possibility of licensing but, because he assumes the efficient licensing contracts are simply infeasible, licensing never occurs in equilibrium.

This paper seeks to remedy this situation by providing a model of internalization by the multinational firm. It focuses not only on the 
decision of the MNE to maintain foreign operations but whether this should be accomplished through FDI or a licensing agreement. In contrast to examples like the one above and the model of Ethier, this model focuses on incentives for FDI that arise from information imperfections in the product market. It is consistent with an observed correlation between advertising expenditures and multinational activity. In the model, the "special firm asset" that must be transferred is the firm's reputation for quality. It arises from the consumers' lack of information on product quality. Because the licensing firm is unable to monitor the licensee costlessly, the licensing agreement must provide incentives for the licensee to maintain the reputation. In effect, the licensing agreement must transfer some of the returns on the reputation to the licensee. FDI avoids the problem. Thus, an incentive is created for FDI. Specifically, the model considers a situation in which a firm (the MaNE) possesses a technology capable of producing either a high quality product or a low quality one. Other firms can only produce the low quality one. Consumers cannot ascertain quality prior to purchase and so are assumed to use reputations to make their purchase decisions. The MNE can either license the technology (and along with it the reputation) to a local producer or operate a branch plant of its own. If the licensee and branch plant are equally efficient, then the need to give a licensee the incentive to maintain the reputation will result in FDI always dominating licensing. This result is given in Section 2.

Section 3 considers the situation in which the licensee has a cost advantage over the MNE branch plant (as many authors like Hymer have suggested). This advantage arises from economies of scope that the licensee can capture by producing both a high and low quality product. In this situation, the choice of licensing or FDI by the MNE depends on a number of factors. In particular, it is shown that FDI will be observed in large 
markets but licensing in small (or speciality) markets. Similarly, licensing results if the high and low quality goods are close substitutes, FDI if they are poor substitutes. Finally, high interest rates make FDI more likely when scope economies are small but less likely when these economies are large.

The final sections include a discussion of trade policy issues and a number of extensions to the model of sections 2 and 3 . One extension of particular interest permits the MNE to choose between exporting and foreign operations of some sort. It is shown that, as the market size changes, the MNE may switch from FDI to licensing or from exporting to some form of foreign operations. The MNE will never switch from licensing to FDI, however. The conclusion contains a discussion of how the results of these models should be interpreted.

2. LICENSING VS. FOREIGN DIRECT IAVESHENT-THE SMMETRIC GASE

It is assumed that there are two countries, the home country and the host country. Firms in each country produce a quality-differentiated good, q. For simplicity it is assumed that quality can take on two values, $q^{\ell}$ and $q^{h}$ with $q^{l}<q^{h}$ indicating that, were goods of quality $q^{l}$ and $q^{h}$ to sell for the same price, consumers would strictly prefer $q^{h} .^{l}$ Initially, it is supposed that a single home country firm has sole access (through a patent, trade secrecy or the like) to a technology that allows it to produce either $q^{l}$ or $q^{h}$. Host-country firms, on the other hand, have access only to the technology for producing $q^{\ell}$. The home-country firm (MNE) is then faced with the decision of whether or not to enter the host-country market (either with $q^{h}$ or $q^{l}$ ) and whether to do so by licensing its technology to a host-country firm or through direct investment in the host country.

The host-country market for $\mathrm{q}^{\ell}$ is assumed to be perfectly competitive. Individual firms produce with indentical U-shaped average cost curves. Costs 
are assumed to take the form of a per-period $f$ ixed cost, $r k^{l}$ and variable costs given by the increasing, convex function $c^{\ell}(x) \geq 0$. Here $r$ is the host-country interest rate and $x$ the output of an individual firm producing $q^{\ell}$. Consumers are assumed able to verify that the quality of any product is at least $q^{\ell}$. Free-entry implies that the equilibrium price of $q^{\ell}$, then, is given by $\mathrm{p}^{-\ell}=\left[r k^{\ell}+c^{\ell}\left(x^{\min }\right)\right] / x^{\min }$, where $x^{\min }$ is the level of $x$ that minimizes average cost. Should the MNE choose to operate a branch plant in the host-country and produce $q^{\ell}$, its costs would be identical to those of any host-country producer of $q^{\ell}$. This is sufficient to guarantee that with perfect information, $q^{\ell}$ will not be produced by the MNE.

Should the MNE choose to operate a host-country branch plant and produce $q^{h}$, then it would incur a per-period fixed cost of $r k^{h}>r k^{l}$ and variable costs given by the increasing convex function $c^{h}(y) \geq 0$ where $y$ is individual. firm output of $q^{h}$ in the host country. It is assumed these costs are such that, for any $y=x \neq 0, c^{h}(y)>c^{\ell}(x)$ and $\frac{d c^{h}}{d y}>\frac{d c^{\ell}}{d x}$. Should the MNE instead choose to license production of $q^{h}$ to a host country producer (either an existing $q^{\ell}$ producer or a new firm), the licensee would incur exactly the same costs. Thus, in particular, a licensee possesses no special cost advantage over a branch plant nor is it a cost disadvantage.

If consumers can perfectly verify quality prior to purchase, then demand for $q^{h}$ is assumed given by the stationary) function $Y=D\left(p^{h}, p^{-\ell}, q^{h}, q^{\ell}\right)$, where, since it is assumed that there is only a single host-country producer of $q^{h}, Y=y$. Consumers are assumed to view $q^{h}$ and $q^{l}$ as substitutes, so that increases in $q^{\ell}$ (or decreases in $p^{-\ell}$ ) reduce $Y$, ceteris paribus. 
Decisions are assumed to occur in each of an infinite number of discrete time periods $t=0,1,2 \ldots$ Each period the licensee/branch plant makes a quality decision (i.e. $q^{h}$ or $q^{l}$ ) and, if $q^{h}$, a price decision $p^{h}$ in order to maximize the present value of profits. Payments are assumed to accrue at the end of each period.

Licensing decisions also must be made each period. The admissable licensing contracts in this problem are given by the set of steady-state contracts defined by the pair $(F, S)$. Here $F$ is a one-time, nonrecoverable payment made by the licensee at the time the contract is first entered into. $S$ is a per-period payment made by the licensee each period the contract continues to be in force. Licensing contracts are negotiated at the end of a given period. If the MNE licenses to a firm with which it had no contract in the previous period, then the MNE offers a pair $(F, S)$ to the new licensee. Should the licensee accept the contract, it immediately makes a payment $F$ to the MNE. Both parties are bound by the contract through the end of the subsequent period. The contract guarantees the licensee the exclusive right to produce the high quality product and binds it to a payment of $s$ at the end of the period. ${ }^{2}$ At the end of any period during which a licensing contract is in force, the MNE and licensee decide whether the contract will be renewed for an additional period. If both sides agree to renew the contract, then the licensee again receives exclusive rights to produce the high quality good in exchange for a payment of $\mathrm{S}$. Should either side decide to terminate the agreement, then the MNE can contract with a new licensee and of fer a new (F,S) pair. Recontracting costs are assumed to be zero. 3

Two points about this contracting problem are worth noting. First, the fact that lump-sum payments are feasible means that conditions are more favorable for licensing. Were lump-sum payments not feasible, licensing fees would introduce distortions that would bias the case toward FDI. Second, 
while the set of feasible contracts is in some sense quite special, the critical constraint imposed by the above contracting process is on the nature of the committments firms can make. In particular, it is not possible for either party to commit to payments after the licensing agreement has been terminated. As will be seen, this assumption is crucial to the results on licensing and FDI when quality is unobservable prior to sale. ${ }^{4}$ It rules out contracts, for instance, that commit the licensee to payments for all future time even if the MNE's reputation has been dissipated (and so the licensing arrangement terminated). It also rules out the possibility of the MNE committing to refund part of $F$ should it choose to switch licensees. As will become apparent were such contracts feasible, the licensing/FDI decision for the MNE would be altered.

Given this framework, the decisions of the MNE can be easily determined. Suppose, first, that consumers can perfectly determine quality prior to purchase. Then, should the MAVE choose to operate a host-country branch plant each period, its profits would be given by

$$
\frac{\Pi^{*}}{r}=\max _{p^{h}} \frac{p^{h} D\left(p^{h}, p^{-l}, q^{h}, q^{\ell}\right)-C^{h}\left[D\left(p^{h}, p^{-l}, q^{h}, q^{\ell}\right)\right]-r k^{h}}{r}
$$

Should the MNE choose to license its technology in a given period, then, given the MNE's inability to commit to a licensee for more than 1 period, the contract can extract no more than $\Pi^{*}$ in payments in any given period. Moreover, in equilibrium, it will extract no less (since a licensee will clearly accept any contract that earns it nonnegative profits). Therefore, either the equilibrium contract will specifiy $F^{*}=0, s^{*}=\Pi^{*}$ with each party willing to renew the contract for an additional period or, if $F^{*}>0, a$ pair $(F, S)$ such that $F^{*}(1+r)+S^{*}=\Pi^{*}$ with the MNE switching licensees each period. $^{5}$ In either case, the MNE earns the same profit by licensing each 
period as by operating a host-country branch plant each period (or any mixture of the two across time). Under the assumptions of the model, therefore, the MNE chooses to license each period.

This result is exactly what should be expected here. Given there exists neither an inefficiency that can be internalized through a nonmarket transaction nor a special firm asset, the MNE has no incentive to choose a direct investment strategy over a simple licensing arrangement. Therefore, one should expect to observe the MNE licensing the technology to produce $q^{h}$.

Suppose, on the other hand, that consumers cannot perfectly determine quality prior to purchase. In situations in which quality warranties are infeasible (due perhaps to difficulties with third party verification of non-performance) an equilibrium response to this uncertainty may be for firms to acquire a "reputation" for high quality. This reputation then would become a "special firm asset", the full return on which could potentially not be capturable with a licensing arrangement. If this is so, an incentive arises for the MNE to operate a host-country branch plant.

To explore this, a standard model of reputation equilibrium is adopted. (See for instance Klein and Leffler (1981), Allen (1984), Shapiro (1983).) In particular, it is supposed that, while consumers can verify whether a particular firm could produce $q^{h}$ (and so can verify the quality of the competitive sector good prior to purchase), they cannot verify whether the potential producer of $q^{h}$ actually produces $q^{h}$ or $q^{\ell}$ without purchasing the good. 6 Instead, in making a purchase decision from the licensee/branch plant, consumers use the fact that price is $p \star^{h}$ (defined in (1) above) and that $q^{h}$ has been produced in all previous periods as a signal that quality is $q^{h}$ this period (it is assumed that consumers ascertain quality correctly after purchase). An observation of a quality $\mathrm{q}^{\ell}$ in any period leads consumers to assume quality will be $\mathrm{q}^{2}$ in all future periods and so to purchase from the 
competitive sector. In this sense, the home-country firm, either through its licensee or branch plant operations, can acquire (or lose) a reputation for high quality in the host country.

Given this set-up, it is well known that a reputation equilibrium in which $\mathrm{q}^{\mathrm{h}}$ is produced each period exists as long as the present value of producing $\mathrm{q}^{\mathrm{h}}$ each period (maintaining a reputation) is at least as large as the value of selling $q^{\ell}$ at price $p^{* h}$ for a single period (losing the reputation). In terms of the present analysis, were the home-country firm to operate a host-country branch plant each period, a reputation equilibrium would exist if

$$
\frac{\Pi^{*}}{r} \geq \frac{p^{*} y^{*}-c^{\ell}\left(y^{*}\right)-r k^{\ell}}{1+r}=\frac{\Pi^{c}}{1+r}
$$

where $y^{*}=D\left(p^{*}, p^{-\ell}, q^{h}, q^{\ell}\right)$. In what follows, it will be assumed that this inequality holds (were it not to hold, the issue of HNE operations in the host-country would not arise).

Given that the inequality in (2) holds, should the MNE choose to license, it prefers that the licensee maintain its (the MNE's) reputation. If the MNE cannot commit the licensee to producing $q^{h}$ and the licensee's choice of quality (and so profits) in a given period is private information in that period, then the MNE can accomplish this only by providing the licensee with some incentive to maintain the reputation. It requires that the per-period payment, $s$, be such that

$$
\frac{\Pi^{*}-s}{r} \geq \frac{\Pi^{c}-s}{1+r}
$$

or

$$
S \leq(1+r) \Pi^{*}-r \Pi^{c}<\pi^{*}
$$


of particular interest is the fact that the previous equilibria are no longer feasible. If $F^{*}=0$ and $S^{*}=\Pi^{*}$, then no licensee has an incentive to maintain the MNE's reputation. Doing so earns a licensee zero profits while

dissipating the reputation yields $\left(\Pi^{c}-\Pi^{*}\right) /(1+r)=\frac{\left[c^{h}\left(y^{*}\right)-c^{\ell}\left(y^{*}\right)\right]+r\left[k^{h}-k^{l}\right]}{1+r}$.

The same would be true for the other contracts involving $F^{*}>0$.

The equilibrium licensing arrangement in this case is the contract given by $F^{*}=0, S^{*}=\Pi^{*}(1+r)-r \Pi^{c}$ with each side renewing the contract every period. ${ }^{8}$ This equilibrium yields the MNE strictly less profits than it earns through F'DI. Therefore, in equilibrium, the MNE chooses FDI over licensing.

In contrast to the perfect information case, the MNE now chooses to transfer the technology internally. This decision arises for two reasons. One, the existence of imperfect quality information results in creation of the asset "reputation". Second, the inability of the MNE and licensee to write contracts that commit each to certain types of payments even if the contract is terminated results in an inefficiency in the market transfer of the reputation. This inefficiency can be avoided if the transfer is carried out internally. Therefore, the MNE chooses FDI over licensing. 9

\section{LICENSING VS. FDI WITH IMPERFECT INFORMATION AND ASYMAETRIC COSTS}

The preceding section showed that, in the absence of certain forms of committment (like third party bonding), the existence of reputations induces the MNE to choose FDI over licensing under all circumstances. This very strong result depends crucially on the assumption that the licensee and host-country branch plant operate with identical costs. This assumption is frequently challenged in the applied literature on MNE's. There it is generally argued that the licensee possesses a cost advantage over the branch plant. If this is the case, licensing may again arise in equilibrium. This possibility is explored below. 
To capture the important aspects of the licensee cost advantage while maintaining some degree of simplicity, we modify the production technology in a fairly straightforward way. Specifically, should the MNE operate a host-country branch plant, its costs are assumed to be as before. On the other hand, should it license its technology, it does so to one of the host-country producers of $q^{l}$. The licensee can produce $q^{h}$ along with $q^{l}$ by upgrading capacity from $k^{\ell}$ to a level $\hat{k}$, with $k^{h} \leq \hat{k}<k^{h}+k^{\ell}=\bar{k}$. This results in the licensee incurring per-period costs for the two goods of $\hat{r k+C^{\ell}}(x)+c^{h}(y)$. Since $\hat{k}<k^{h}+k^{\ell}$, the licensee's production displays economies of scope. In essence, the ability of the licensee to utilize its capacity in both the $q^{h}$ and $q^{l}$ markets gives it a cost advantage over an MNE branch plant. ${ }^{10}$ If the licensee decides not to produce $q^{h}$ (i.e. it chooses to dissipate the MNE's reputation by producing $q^{l}$ ), then demand for $q^{h}$ is assumed to be such that the cost-minimizing solution for the licensee is to make a second capacity investment, $k^{l}$, rather than bear the increased marginal costs from using existing capacity. In this case, then, the licensee incurs costs of $2 r k^{\ell}+c^{\ell}(x)+c^{\ell}(y)$ (from serving both part of the host-country market for $q^{\ell}$ and all of the market for $q^{h}$ with a good of quality $q^{\ell}$ ). To maintain the assumption that production of $\mathrm{q}^{\ell}$ is less costly than production

of $q^{h}$, it is assumed that $r k^{\ell}+c^{\ell}(y)<r\left(k-k^{\ell}\right)+c^{h}(y) .11$ As before, it is assumed that the MNE cannot monitor the licensee's quality (or capacity) choice prior to sale.

To determine the MNE's equilibrium strategy, one again need only compare the profits from FDI with the equilibrium licensee fee that the MNE can collect. Thus, should the MNE operate a branch plant each period, its profits are given by (1) as previously. Should it license, then by an argument identical to that in section 2 , the equilibrium contract has $F^{*}=0$ and $S^{*}$ 
equal to the maximum per-period payment consistent with the licensee maintaining the reputation. Licensing dominates FDI as long as $S^{*} \geq \Pi^{*}$. Since the licensee can continue to produce $x^{\min }$ and receive $\mathrm{p}^{-l}$ in the market for $q^{\ell}$, its cost of producing $q^{h}$ is effectively $c^{h}\left(y^{*}\right)+r\left(k^{l}-k^{\ell}\right)$. If one lets $\Pi^{L}=p^{*} y^{*}-C^{h}\left(y^{h}\right)-r\left(k-k^{l}\right)$ and $\Pi^{L C}=p^{*} y^{*}-C^{l}\left(y^{*}\right)-r k^{l}$, then the condition for licensing to be an equilibrium is simply that

$$
\frac{\Pi^{L}-\Pi^{*}}{r} \geq \frac{\Pi^{L C}-\Pi^{*}}{1+r}
$$

Some simple algebra shows that this condition can be rewritten as

$$
\bar{k}-\hat{k}-r\left(\hat{k}-2 k^{\ell}\right) \geq c^{h}\left(y^{*}\right)-c^{\ell}\left(y^{*}\right)
$$

That is, if (5) holds, then licensing dominates EDI in equilibrium.

An immediate implication of (5) is that, contrary to the results of the preceding section, licensing now may be an equilibrium strategy. Because the licensee can take advantage of scope economies, it may be possible for the MNE to extract at least $\Pi^{*}$ in license fees and stj.11 leave the licensee with enough profits to induce it to maintain the reputation. In such cases, licensing becomes an equilibrium strategy for the MNE.

By an analysis of (5) it is possible to obtain a number of predictions regarding the circumstances under which either licensing or FDI will be observed. Consider, for instance, how the size of the market for $q^{h}$ effects the licensing/FDI decision. Let a parameterize demand for $q^{h}$ and be such that increases in a lead, in equilibrium, to increases in both $p *^{h}$ and $y *$. Further, define the variable $z$ as

$$
z=\bar{k}-\hat{k}-r\left(\hat{k}-2 k^{\ell}\right)-c^{h}\left(y^{*}\right)+c^{\ell}\left(y^{*}\right)
$$

Then, it is clear from (6) that increases in a lead to a reduction in $z$. That 
is, changes that increase the size of the market for $q^{h}$ make licensing less desirable. This is due to the fact that, the larger is the market, the larger are the cost savings to the licensee from producing $q^{l}$ rather than $q^{h}$ (i.e. from dissipating the MNE's reputation). To prevent the licensee from doing this, the MNE must leave it with larger returns from producing $q^{\text {h }}$. Ultimately the problem can become severe enough that FDI dominates licensing. A prediction of the model, then is that licensing is more likely to be observed in small markets and FDI in large ones.

In the same vein, a variable that determines demand for $q^{h}$ is the value of $q^{\ell}$. As noted earlier, consumers are assumed to view $q^{h}$ and $q^{\ell}$ as substitutes so that increases in $q^{\ell}$ reduce the demand for $q^{h}$. The preceding results then imply that the higher the quality of $q^{l}$ that can be obtained for a given cost, the more attractive licensing becomes for the home-country firm. Further, it is clear from (6) that, should increases in $q^{l}$ come at the expense of higher costs, this result is merely strengthened. Therefore, where there are good substitutes for the home-country product one should observe licensing, while the lack of substitutes is more likely to result in FDI.

Results can also be obtained concerning the effects of fixed costs on the licensing/FDI decision. From (6), should $k^{l}$ increase relative to $\hat{k}, z$ increases and so licensing becomes more attractive. This is simply a result of the fact that an increase in $k^{\ell}$ relative to $\hat{k}$ implies larger economies of scope for the licensee. This means that it is more profitble for the 1 icensee to maintain the MNE's reputation, making licensing a more attractive option. Increases in $\mathbf{k}^{\mathrm{h}}$ that leave $\hat{k}$ unchanged (or, if not, are such that $\left.d k^{h}>(1+r) d \hat{k}\right)$ result in a similar outcome. Such a change increases the cost to the MNE of branch-plant operations relative to licensing. This, in turn, reduces the value of $S$ that the MaNe must obtain to prefer licensing to FDl, thereby leaving that licensee with a larger return from producing 
$q^{h}$. Again, by essentially increasing the size of the economies of scope, the increase in $\mathrm{k}^{\mathrm{h}}$ relative to $\hat{k}$ increases the likelihood that licensing is observed.

Finally, the effect of $r$ on the licensing decision can be considered. From (6), the effect clearly depends on whether $\hat{k}<2 k$. If $k>2 k$ then increases in $\mathbf{r}$ reduce $z$ and make licensing less attractive. The opposite is true if $k<2 k$. This ambiguity arises from the fact that increases in $r$ produce counterbalancing effects. One is that increases in $r$ make the dissipation of a reputation more attractive. That is, as the licensee discounts the future more heavily, the one-period gains from the production of $q^{\ell}$ become more attractive. The other is that increases in $r$ increase the returns from the scope economies resulting from the production of $q^{h}$. If $\hat{k}>2 k^{\ell}$, the scope economies are not sufficiently large for the latter to offset the former one. Thus, as $r$ increases, the MNE is less likely to license its technology. The opposite is true if $k<2 k$ (i.e. large scope economies).

\section{EXTENSIONS}

This section considers a number of extensions to the model of Section 3. It incorporates the model of Section 3 in one in which the MNE must also make an export vs. foreign operations decision. As well, it considers the effects both of future uncertainty and the ability of the MNE to monitor the license on the licensing/FDI decision. These extensions generate a number of additional predictions.

\section{A) Demand growth and exporting}

To this point, attention has been focused solely on the MNE's decision to license as opposed to operating a branch plant. Clearly another alternative is for the MNE simply to export to a host-country. One way of 
adding this additional alternative is to amend the model of section 3 to allow for demand growth over time. In particular, suppose that demand at time $t$ is given by the function $\left.y_{t}=D_{t} p_{t}^{h}, p_{t}^{-l}, q_{t}^{h}, q_{t}^{l}, t\right)$. Further, assume that the demand function possess the following properties (in addition to the ones assumed for the stationary case).

i) at $t=0$, the one-period maximized profits from exporting $\left(\pi_{0}^{e}\right)$ exceed the one-period maximized profits from a host-country branch plant $\left(\Pi_{0}^{*}\right)$.

ii) $\Pi_{t}^{e}-\Pi_{t}^{*}$ is monotone decreasing in $t$. Further, there exists a finite time $\bar{t}$ such that, for all $t<\bar{t}, \pi_{t}^{e}-\pi_{t}^{*}>0$ while, for all $t \geq \bar{t}, \Pi_{t}^{e}-\Pi_{t}^{*} \leq 0$

iii) Demand is bounded for all $t$.

iv) If the home-country firm could choose only to operate a branch plant or export, a reputation equilibrium would exist at every $t$. This specification adds the important feature that the home-country firm would prefer to export rather than operate a branch plant for all $t \in[0, \bar{t}-1]$. To solve for MNE's optimal strategy, it is useful to define a new variable $s_{t}$. This is a per-period license fee defined such that

$$
s_{t}=\left\{\begin{array}{cc}
\pi_{t}^{e} & t \in[0, \bar{t}-1] \\
\Pi_{t}^{*} & t \geq \bar{t}
\end{array}\right\}
$$

If, for all $t \geq \hat{t}$, the home-country firm can extract the license fee $s_{t}$ from a licensee while still inducing the licensee to maintain a reputation, then licensing will be an equilibrium strategy for all $t \geq \hat{t}$. That is, if at each 
$t_{1} \geq \hat{t}$

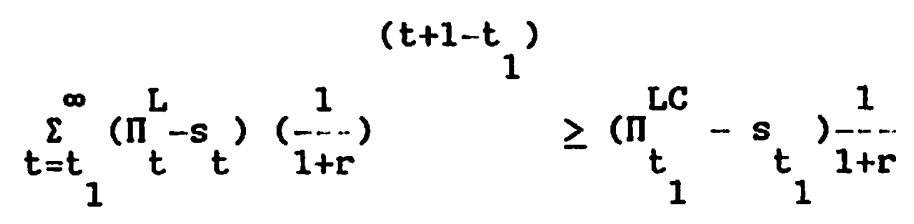

then licensing will be an equilibrium strategy at each $t_{1} \cdot 12$

Given that $\Pi_{t}^{L}$ and $\Pi_{t}^{*}$ differ only by a constant, demand condition $\left.i i\right)$ implies that the left-hand side of (7) is monotone increasing for all

$t<\bar{t}$. Further it approaches the constant $\bar{k}-\hat{k}$ as $t$ approaches $\bar{t}$. As for the right-hand side of (7), note that for $t<\bar{t}$, it can be written as $\left(\Pi_{t}^{L C}-\Pi_{t}^{*}\right)-\left(\Pi_{t}^{e}-\Pi_{t}^{*}\right)$. From results previously, the first term of this expression is increasing in $t$ while $-\left(\Pi_{t}^{e}-\pi_{t}^{*}\right)$ is increasing in $t$ from $\left.i i\right)$ above. Therefore, the right-hand side is monotone increasing in $t$ as well. Further, for $t \geq \bar{t}$, since the left-hand side is a constant, (7) can be expressed as

$$
\bar{k}-\hat{k}-r\left(\bar{k}-2 k^{l}\right) \geq c{ }^{h}\left(y_{t}^{*}\right)-c^{l}\left(y_{t}^{*}\right),
$$

with the right-hand side increasing in $t$.

If it is supposed, then, that at $t=0$ (7) is violated, the MNE will export rather than license. This is because, even if a licensee were to earn the maximum return possible, it would still dissipate the home-country firm's reputation at $t=0$. Since the right and left-hand sides of ( 8 ) are increasing for all $t<\bar{t}$, there are two possible outcomes for $t>0$. One is that the right-hand side increases everywhere more quickly than the left so that at $t=\bar{t},(8)$ is violated. In this case, the results of section 3 imply that (8) is violated for all $t>\bar{t}$. Therefore, licensing is not observed. The MNE simply switches from exporting to operating a host-country branch plant. 
The other possibility is that the left-hand side increases more quickly so that at $t=\bar{t},(8)$ is satisfied. Further (8) is satisfied for all $t>\bar{t}$ (i.e. while the right-hand side continues to increase, demand never grows large enough for (8) to be violated). In this case, the MNE adopts a policy of switching at some $t \leq \bar{t}$ from exporting to licensing production to a host-country producer.

What might seem to be a third possibility is to observe the home-country firm initially exporting, then switching to licensing and finally FDI. This cannot happen. Were the home-country firm to license for only a finite number of periods, the licensee would always have an incentive to dissipate the reputation before the license were revoked. The home-country firm, therefore, would never choose this strategy.

Finally, note that the case in which demand for $q^{h}$ shrinks over time can be dealt with analogously. This might occur, for instance, because $q^{2}$ is increasing over time (as in section 3). In this case, a situation in which the MNE switches from FDI to licensing (as $q^{l}$ increases) might be observed in equilibrium.

\section{B. Uncertain ending time}

In the preceding analysis, it is assumed that the time horizon is infinite and known to be so with certainty. This is easily replaced by an assumption of an uncertain time horizon where the probability that any given period $t=0,1,2 \ldots$ is the last is $\phi(1-\phi)^{t}$. Then, if this uncertainty holds both for a host-country branch plant and a licensee, the licensing condition becomes

$$
\frac{\Pi^{L}-\Pi^{*}}{r+\phi} \geq \frac{\Pi^{L C}-\Pi^{*}}{1+r}
$$

Clearly, increases in $\phi$ make licensing less attractive. The uncertainty 
about future returns gives the licensee more incentive to produce $q^{\ell}$ in the current period and dissipate the HNE's reputation. Therefore, in situations in which the future of the market is very uncertain, either no foreign

operations at all or provision of $\mathrm{q}^{\mathrm{h}}$ through exports/FDI should be observed. If, on the other hand, the uncertainty is only as to whether the MNE will be able to continue operating a branch plant (or exporting) then the result is reversed. This uncertainty will have the effect of reducing the minimum license fee needed to have licensing dominate FDI. This will cause the left-hand side of (10) to increase more than the right, causing licensing to occur more often.

\section{Monitoring the licensee}

In what has preceded, it has been assumed that the MNE cannot monitor the quality of the licensee's product prior to sale. This assumption can easily be relaxed to allow for monitoring that simply results in increased costs to the licensee should it produce $q^{l}$ (i.e. try to dissipate the MNE's reputation). 13 Suppose, for instance, that the licensee's variable cost of production for $q^{\ell}$ is given by $c^{l}(y, \sigma)$ where $c_{\sigma}^{l}>0$. Further, suppose that the value of $\sigma$ is determined by the MNE as part of the licensing agreement at a cost $x(\sigma)\left(x^{\prime}>0\right)$. Then, as long as the MNE can extract at least $\Pi^{*}+\chi(\sigma)$ in license fees each period while still inducing the licensee to produce $q^{h}$, the MNE will choose to license. That is, licensing is chosen as long as

$$
\frac{\Pi^{L}-\Pi^{*}-x(\sigma)}{r} \geq \frac{p^{*} y^{*}-c^{\ell}\left(y^{*}, \sigma\right)-r k^{\ell}-\Pi^{*}-x(\sigma)}{1+r}
$$

If large increases in $c^{\ell}()$ can be achieved at very low cost to the home-country firm, then licensing now will be observed in cases where it would not have been observed previously. However, if increases in $c^{\ell}($ ) are very expensive, then the pattern of licensing and FDI will be a little different. 


\section{TRADE POLICY ISSUES}

This section analyzes the welfare implications of several host-country commerical policy actions that seem to be empirically relevant in the context of multinational activity. Rather than examine many possible cases, the discussion is restricted to the case of stationary demand in the host country. This makes it possible to evaluate certain policies through a simple evaluation of their effects on steady-state consumption in the host-country. The assumption that monitoring is prohibitively expensive is also maintained throughout. Finally, the analysis is limited to the case in which the marginal costs functions are the same under licensing and FDI and, for the same level of output, exporting results in a higher total marginal cost (production plus shipping) than either of the other options.

The host-country welfare criterion applied to evaluate the policies will be the sum of the change in consumer surplus (via a change in the availability and price of $Y$ ), the change in profits to the host-country licensee (when relevant) and the change in host-country government revenues (if any).

\section{A. Banning FDI}

Banning FDI in the host-country may lead to the MNE choosing either the licensing or the exporting option (or not to serve the host-country at all). Which outcome occurs depends on such things as the host-country market size, discount rate, etc. Rather than belabour the point let us simply assert that each alternative will be chosen for some set of parameter values.

It is clear from the above assumptions and results that the welfare effects of banning FDI depend on which alternative is chosen. Welfare will improve if licensing is chosen, since the host-country will caputre rents that would otherwise accure to the MNE (necessary to support the reputation equilibrium) and the price of $Y$ will not change (the equal marginal cost 
assumption). If exporting is chosen, however, welfare deteriorates as the price of $Y$ increases with no offsetting advantages.

\section{B. Banning imports}

Suppose that the host-country, for whatever reason, wishes to generate domestic production of $Y$. (One reason is a real or mistaken belief that it will reduce unemployment, something that is outside the scope of this paper). Suppose that the host-country market is large enough to support domestic production of $Y$ and that the country levies a sufficiently high tariff to induce the MNE to switch from exporting. Welfare will increase in the host country if the MNE chooses a branch plant and, by transitivity, increases even more if it chooses licensing. Banning imports forces a price reduction and also generates domestic profits if licensing is chosen. This result is of course sensitive to the assumption that the marginal cost of domestic production is less than the total marginal cost from the MNE's home plant.

\section{Differential taxation on FDI}

A not-uncommon practice is for countries to penalize foreign firms in subtle or not-so-subtle ways through domestic tax legislation. While the various details of such policies can hardly be captured here, certain principles can be easily illustrated by considering two special cases. First, a pure-profits tax on FDI is welfare improving provided that it does not cause the MNE to switch to exporting. If the MNE absorbs the tax or switches to licensing, $p_{y}^{h}$ stays constant while the host-country captures some of the rent. If the MNE switches to exporting, no rent is captured, consumer price rises, and the host-country is worse off. 
Few countries' corporate taxes are equivalent to a non-distortionary pure-profits tax. An alternative is to model a distortionary tax as a simple output tax on FDI. Comments regarding the MNE switching to licensing or exporting made with respect to the pure profits tax continue to apply but more complex outcomes occur when the MNE continues to choose FDI. The problem is that such an output tax generates two conflicting changes for the host country. First, there is a deadweight loss as the distortionary tax increases marginal cost and (generally) reduces output. Second, there is a rent transfer from the aNE to the host country government. The latter effect could outwiegh the former, generating a welfare gain for the host country.

\section{SUMAARY AND CONCLUSIONS}

This paper has considered a problem in which, because of imperfect consumer information about quality, a firm acquires a reputation. Because the firm cannot monitor a licensee to guarantee that the licensee maintains the reputation, the licensing contract must provide incentives for this. This fact may lead the firm to choose a strategy of direct investment rather than licensing. By a direct ownership arrangement, the firm guarantees that its reputation is maintained.

While the analysis is couched in terms of a reputation model, it may be viewed as applicable to a much broader set of circumstances in which firms (principals) have imperfect control of licensees (agents). A wealth of empirical evidence (see, for instance, Nicholas (1986), Casson (1985) and Rugman (1985)) suggests the importance of this problem in the firm's decision to operate branch plants and subsidiaries. In future research, we hope to investigate the problem further. 


\section{Footnotes}

$1_{\text {The analysis that follows would hold equally well were } q \text { a continuous }}$ variable and part of a firm's optimzation problem. The assumption that $q$ can take on only two values simply removes the additional complication that would otherwise result.

2

${ }^{2}$ clearly, as long as this is possible, it will generally be in the MNE's interest to commit to an exclusive licensing arrangement.

3

This and the assumed stationarity of demand and costs imply that little (if anything) is lost by restricting the contract to a constant, per-period payment, $s$, for as long as the contract is in effect.

4

To be precise, if the quality choice and profits of a licensee are private information in a given period (as will be assumed), then a general licensing contract can only condition on past information. Given the reputation equilibrium that is employed when consumers cannot ascertain quality, such a contract will dominate the contracts assumed here only if payments can be committed to after the contract has been terminated (either by the licensee dissipating the MNE's reputation or the MNE switching

licensees). The committment contracts given as examples in the text have this property and dominate a simple (F,S) pair. A similar contract that would also have this property would be one that required the licensee to pay to the MNE all profits obtained from dissipating the reputation. Since the dissipation of its reputation could only be ascertained by the MNE in the subsequent period, the MNE would need some way of recovering these gains after the fact. The contracting problem considered here assumes that this is not possible.

5

$F>0$, and $F(1+r)+S>\Pi^{*}$ could not be an equilibrium since, were a licensee to accept this contract, it would pay the MNE to switch licensees after one period. Given $F$ is not refundable, the licensee would make negative profits. Anticipating this, the licensee would not accept such a contract. The complete details of the licensing equilibrium are provided in the Appendix.

6 This can be thought of as capturing a situation in which the MNE is identified by some brand name that it can keep from being employed by anyone other than its branch plant/licensee. Alternatively, one can think of this assumption as being the appropriate approximation to a model in which $q$ is a continuous variable and consumers can perfectly ascertain quality only so long

as $q \leq q^{\ell}$. Then, consumers could perfectly ascertain the quality of the competitive sector. However, the licensee/branch plant could claim to have quality $\mathrm{q}^{\mathrm{h}}$ and produce quality $\mathrm{q}^{\ell}+\varepsilon$ and go undetected. For a model in which other $q^{\ell}$ producers could claim to have the $q^{h}$ technology see Grossman and Shapiro (1986). 
It is assumed here that $s / r \geq \Pi^{c} /(1+r)$, so that the MNB can extract enough in license fees to make its reputation valuable to it.

8 Were the MNE to switch licensees, no licensee would have an incentive to maintain the reputation. Therefore, the MNE and licensee must have incentives to renew the contract each period. This occurs only if $F=0$. See the Appendix for details.

9

9 As argued above, the inefficiency of licensing would be removed if some scheme like third party bonding were possible. Such a scheme would require the licensee to make a nonrecoverable payment $F>0$ to a third party who would only tranfer the entire amount to the MNE if the contract were renewed every period. The same result would occur if the licensee could commit to paying penalties should it dissipate the MNE's reputation. If such committments are not possible, then the essentials of the analysis presented here would continue to hold in more general settings.

${ }^{10}$ An implicit assumption here is that the multinational branch plant chooses not to produce both $q^{h}$ and $q^{\ell}$. Production of both $q^{h}$ and $q^{\ell} \operatorname{could}$ be achieved either through acquisition of a host-country producer of $q^{2}$ or new entry into the host-country market for $q^{\ell}$. It is assumed here that FDI or licensing dominates either of these options. This could be the case if, for instance, there were significant acquisition costs and entry into the host-country market for $q^{\ell}$ required a large sunk cost. The later would imply that, were the home-country firm simply to enter the host-country market for $q^{\ell}$, the existing producers would not exit. This would drive price below average cost (inclusive of the sunk entry cost). Were the sunk entry cost large enough, this could make entry into the $q^{\ell}$ market undesirable.

${ }^{11}$ It is assumed here that, should the licensee sel1 $q^{2}$ in both markets, it must produce $x$ and $y$ in separate production runs to avoid detection by the MNE. This assumption could be dropped with no cost other than the proliferation of additional notation. The same is true were the licensee assumed to produce all output with existing capacity.

${ }^{12}$ It is assumed here that the licensing agreement now simply specifies an initial payment $F$ at the beginning of the agreement and a single period payment $s_{t}$ determined each period the agreement is renewed.

${ }^{13}$ This sort of monitoring would be such that the licensee could only circumvent the process by expending some amount of resources. If, for instance, cost savings from the production of $q^{l}$ arise from the use of inferior (and lower priced) inputs, monitoring might take the form of the MNE requiring the licensee to buy inputs from him. Then, to obtain the cost savings from the production of $q^{l}$, the 1 icensee must resell these inputs and acquire the lower priced ones. The resale costs are what are captured here. 


\section{REFERENCES}

Allen, F. (1984), "Reputation and Product Quality", Rand Journal of Economics 15, 311-27.

Casson, M. (1985), "The Economic Theory of the Multinational Enterprise: Its Contribution to the Theory of the Firm", University of Reading Working Paper.

Caves, R, (1982), Multinational Enterprise and Economic Analysis, Cambridge University Press.

Dunning, J. (1958), American Investment in British Manufacturing Industry, Allen and Unwin.

Eastman, H. and S. Stykolt (1967), The Tariff and Competition in Canada. Macmillan.

Ethier, W. (1986), "The Multinational Firm," forthcoming, Quarterly Journal of Economics

Helpman, E. (1984), "A Simple Theory of International Trade with Multinational Corporations", Journal of Political Economy 92, 451-471.

Horstmann, I. and Markusen (1986), "Strategic Invesments and the Development of Multinationals", forthcoming International Economic Review.

Hymer, S. (1960) The International Operations of National Firms: A Study of Direct Foreign Investment. Ph.D. Thesis, Massachusetts Institute of Technology, published by MIT press, 1976.

Klein, B. and K. Leffler, "The Role of Market Forces in Assuring Contractual Performance", Journal of Political Economy 89, 615-41.

Grossman, G. and C. Shapiro (1986) "Counterfeit Product Trade" Woodrow Wilson School Discussion Paper \#107.

Markusen, J. (1984), "Multinationals, Multi-Plant Economies, and the Gains from Trade", Journal of International Economics 16, 205-26.

Nicholas, S. (1983), "Agency Contracts, Institutional Modes, and the Transition to Foreign Direct Investment by British Manufacturing Multinationals Before 1939", Journal of Economic History 43, 675-686.

Nicholas, S. (1986), "Theory of the Multinational Enterprise as a Transactional Mode: Pre-1939 British Overseas Investment," University of New South Wales Working Paper.

Rugman, A. (1985), "New Theories of the Multinational Enterprise: An Assessment" Dalhousie University Working Paper.

Shapiro, C. (1983), "Premiums for High Quality Products as Returns to Reputation", Quarterly Journal of Economics 98, 659-79. 


\section{Appendix}

This appendix contains a formal statement of the results on licensing contained in section 2 . The licensing game is as described there. The equilibrium concept in the subgame perfect Nash equilibrium with each firm's strategy maximizing its stream of profits for every subgame given the strategy of the other firms. It is assumed that a potential licensee earns zero profits in a given period should it not be part of a licensing agreement.

Given these assumptions, a perfect equilibrium strategy for a licensee must involve the licensee accepting/renewing a licensing agreement if that agreement yields nonnegative profits. This yields the first result. It is:

Lemma 1: For a licensing arrangement $(F, S)$ to be an equilibrium with perfect information, it must be that $F+(S / r) \leqq \Pi^{*} / r$.

Proof: Suppose not. If $F+(S / r)>\Pi^{*} / r$, then, should the home-country firm continue the licensing arrangement every period, the licensee would earn negative profits. This, though, implies that the licensee could be better off choosing reject rather than accept. Should the home-country firm terminate the contract after $T$ periods, then since $r F+S>\Pi^{*}$, the licensee would also earn negative profits. Again, it could be made better off by choosing reject. Therefore $F+(S / r) \leq \Pi^{*} / r$. Q.E.D.

In fact, given the equilibrium strategy of a licensee and perfect information, an equilibrium licensing agreement must be such that $F+(S / r)=\Pi^{*} / r$. In addition, the constant (F*, $\left.S^{*}\right)$ must be such that the following is true:

Proposition: With perfect information on quality, the set of equilibrium contracts $\left(F^{*}, S^{*}\right)$ is unique up to the condition $F(1+r)+S=\Pi^{*}$. 
Proof: It is clear that $F^{*}=0, S^{*}=\Pi^{*}$ is an equilibrium and satisfies the above condition. The only issue then is the uniqueness one. Suppose that along the equilibrium path a subgame were reached in which $\hat{F}>0, \hat{s}<\pi^{*}$. There are two possibilities as regards future play of the game. One is that the home-country firm's equilibrium strategy will call for it to play continue for $T$ periods and then offer a new $(F, S)$ pair to another licensee. However, if this is an optimal strategy at time $T$, it must also be optimal at $T-1$. If it is optimal at $T-1$, it must be optimal at $T-2$ and so on. This, though, implies that continuing for $T$ periods cannot be optimal. Therefore, it must be either that continuing is optimal for all periods or no periods.

Suppose continuing were optimal for all periods. Then, since the homecountry firm could earn $\Pi^{*} / r$ by using the pair $F=0, S=\Pi^{*}$, it must be that $\hat{\mathrm{F}}+\frac{\hat{\mathrm{S}}}{\hat{\mathrm{r}}}=\frac{\Pi^{*}}{\mathbf{r}^{-}}$. If this is the case, however, then it must be that the homecountry firm could offer $(\hat{F}, \hat{S})$ to a new licensee next period and earn larger profits than from continuing. This, though, contradicts the fact that continuing for all periods is optimal.

Therefore, not continuing must be the optimal solution. In this case, for accept to be a best-reply for the licensee, it must be that $F(1+r)+S \leq \Pi^{*}$. The optimal strategy for the home-country firm is to set $F(1+r)+S=\Pi^{*}$. Q.E.D.

REMARK: Note that were there any recontracting costs, the only equilibrium would be $F^{*}=0, S^{*}=\Pi^{*}$. Also, in the case of imperfect information, the set of single period contracts with $F>0$ are no longer equilibria. The fact that the licensee would be changed each period would cause any licensee to dissipate the home-country firm's reputation. This leaves only $F^{*}=0$, $S^{*}=(1+r) \Pi^{*}-r \Pi^{c}$ (i.e. the maximum one-period fee consistent with the licensee maintaining reputation). 
8401C Harrison, Glenn w. and Manning, Richard. BEST APPROXIMATE AGGREGATION OF INPUT-OUTPUT SYSTEMS.

8402C Parkin, Michael. CORE INFLATION: A REVIEW ESSAY.

8403C Blomqvist, Áke, and McMahon, Gary. SIMULATING COMMERICAL POLICY IN A SMALL, OPEN DUAL ECONOMY WITH URBAN UNEMPLOYMENT: A GENERAL EQUILIBRIUM APPROACH.

8404C Wonnacott, Ronald. THE THEORY OF TRADE DISCRIMINATION: THE HIRROR IMAGE OF VINERIAN PREFERENCE THEORY?

8405C Whalley, John. IMPACTS OF A 50\% TARIFF REDUCTION IN AN EIGHT-REGION GLOBAL TRADE MODEL.

8406C Harrison, Glenn W. A GENERAL EQUILIBRIUM ANALYSIS OF TARIFT REDUCTIONS.

8407C Horstmann, Ignatius and Markusen, James R. STRATEGIC INVESTMENTS AND . THE DEVELOPMENT OF MULTINATIONALS.

8408C Gregory, Allan W. and McCurdy, Thomas H. TESTING THE UNBIASEDNESS HYPOTHESIS IN THE FORINARD FOREIGN EXCHANGE MARKET: A SPECIFICATION ANALYSIS.

$8409 \mathrm{C} J o n e s$, Ronald $\mathrm{H}$. and Klerzkowsk1, Henryk. NEIGHBORHOOD PRODUCTION STRUCTURES WITH APPLICATIONS TO THE THEORY OF INTERNATIONAL TRADE.

$8410 \mathrm{C}$ Neller, Paul and Yano, Makoto. THE ROLE OF FUTURES MARKETS IN INTERNATIONAL TRADE: A GENERAL EQ̣UILIBRIUM APPROACH.

$8411 \mathrm{C}$ Brecher, Richard A, and Bhagwat1, Jagdish N. VOLUNTARY EXPORT RESTRICTIONS VERSUS IMPORT RESTRICTIONS: A WELFARE-THEORETIC COMPARISON.

$8412 \mathrm{C}$ Ethter, WIIfred J. ILLEGAL IMMIGRATION.

8413C Eaton, Jonathon and Gene M. Grossman. OPTIMAL TRADE AND INDUSTRIAL POLICY UNDER OLIGOPOLY.

8414C Wooton, Ian. PREFERENTIAL TRADING AGREEMENTS - A 3xn MODEL.

8415C Parkin, Michael. DISCRIMINATJNG BETWEEN KEYNESIAN AND CLASSICAL THEORIES OF THE BUSINESS CYCLE: JAPAN 1967-1982

8416C Deardorff, Alan V. FIRless FIRwoes: HOW PREFERENCES CAN INTERFERE WITH THE THEOREMS OF INTERNATIONAL TRADE.

3417C Greenwood, Jeremy. NONTRADED GOODS, THE TRADE BALANCE, AND THE BALANCE OF PAYNENTS. 
8418C Blomqvist, Ake and Shar 1f Mohammad. CONTROLS; CORRUPTION, AND COMPETITIVE RENT-SEEKING IN LDCs.

8419C Grossman, Herschel I. POLICY, RATIONAL EXPECTATIONS, AND POSITIVE ECONOMIC ANALYSIS.

8420C Garber, Peter M. and Robert G. King. DEEP STRUCTURAL EXCAVATION? A CRITIOUUE OF EULER EQUATION METHODS.

$8421 C$ Barro, Robert J. THE BEHAVIOR OF U.S. DEFICITS.

8422C Persson, Torsten and Lars E.0. Svensson. INTERNATIONAL BORROWING AND TIME-CONSISTENT FISCAL POLICY.

84236. Obstfeld Maurice. CAPITAL CONTROLS, tHE DUAL EXCHANGE RATE, AND DEVALUATION.

8.424C Kuhn, Peter. UNION PRODUCTIVITY EFFECTS AND ECONOMIC EFFICIENCY.

8425C Hamilton, Bob and John whalley. TAX TREATMENT OF HOUSING IN A DYNAMIC SEỌUENCED GENERAL EỌUILIBRIUM MODEL.

$\because 426 \mathrm{C}$ Hamilton, Bob, Sharlf Mohammad, and John Whalley. RENT SEEKING AND THE NORTH-SOUTH TERMS OF TRADE.

8427C Ndams, Charles and Jeremy freenwood. DUAL EXCHANGE RATE SYSTEMS AND CAPITAL CONTROLS: AN INVESTIGATION.

3428 Loh, Choon Cheong and Michael R. Veall. A NOTE ON SOCIAL SECURITY AND PRIVATE SAVINGS IN SINGAPORE.

8429 Whalley, John. REGRESSION OR PROGRESSION: THE TAXING OUESTION OF INCIDENCE ANALYSIS.

3430 Kuhn, Peter. WAGES, EFFORT, AND INCENTIVE-COMPATIBILITY IN LIFE-CYCLE EMPLOYMENT CONTRACTS.

8431 Greenwood, Jeremy and Kent P. Kimbrough. AN INVESTIGATION IN THE THEORY OF FOREIGN EXCHANGE CONTROLS.

8432 Greenwood, Jeremy and Kent P. Kimbrough. CAPITAL CONTROLS AND THE INTERNATIONAL TRANSMISSION OF FISCAL POLICY.

8433 : Nguyen, Trien Trien and John Whalley. ỆUILIBRIUM UNDER PRICE CONTROLS WITH ENDOGENOUS TRANSACTIONS COSTS.

8434 Adams, Charles and Russell S. Boyer. EFFICIENCY AND A SIMPLE MODEL OF EXCHANCE RATE DETERMINATION. 
8435 Kuhn, Peter. UNIONS, ENTREPRENEURSHIP, AND EFFICIENCY.

8436 Hercowitz, Zv1 and Efraim Sadka. ON OPTIMAL CURRENCY. SUBSTITUTION POLICY AND PUBLIC FINANCE.

8437 Lenjosck, Gordon and John Whalley, POLICY EVALUATION IN $A$ SMALL OPEN PRICE TAKING ECONOMY: CANADIAN ENERGY POLICIES.

8438 Aschauer, David and Jeremy Greenwood. MACROECONOMIC EFFECTS OF FISCAI POLICY.

8439C Hercowitz, ZV1. ON THE DETERMINATION OF THE EXTERNAL DEBT: THE CASE OF ISRAEL.

8440C Stern, Robert M. GLOBAL DIMENSIONS AND DETERMINANTS OF INTERNATIONAL TRADE AND INVESTMENT IN SERVICES.

8441C Deardorff, Alan V. COMPARATIVE ADVANTAGE AND INTERNATIONAL TRADE AND INVESTMENT IN SERVICES.

8442C Daly, Donald J. TECHNOLOGY TRANSFER AND CANADA'S COMPETITIVE PERFORMANCE.

8443C Grey, Rodney de C. NEGOTIATING ABOUT TRADE AND INVESTMENT IN SERVICES.

8444C Grossman, Gene M. and Carl Shapiro. NORMATIVE ISSUES RAISED BY INTERNATIONAL TRADE IN TECHNOLOGY SERVICES.

3445C Chant, John F. THE CANADIAN TREATMENT OF FOREIGN BANKS: A CASE STUDY IN THE WORKINGS OF THE NATIONAL TREATMENT APPROACH.

8446C Aronson, Jonathan D. and Peter F. Cowhey. COMPUTER, DATA PROCESSING, AND COMMUNICATION SERVICES.

8447C Feketekuty, Geza. NEGOTIATING STRATEGIES FOR LIBERALIZING TRADE AND INVESTMENT IN SERVICES.

8448C Harrison, Glenn, W. and E.E. Rutstrom. THE EFFECT OF MANUFACTURING SECTOR PROTECTION ON ASEAN AND AUSTRALIA: A GENERAL ENUILIBRIUM ANALYSIS. 
8501C Greenwood, Jeremy and Kent P. KImbrough. FOREIGN EXCHANGE CONTROLS IN A BLACK MARKET ECONOMY.

8502C Horstmann, Ignatlus and James R. Markusen. UP YOUR AVERAGE COST CURVE: INEFFICIENT ENTRY AND THE NEW PROTECTIONISM.

8503C Gregory, Allan $W$. TESTING INTEREST RATE PARITY AND RATIONAL EXPECTATIONS FOR CANADA AND THE UNITED STATES.

8504C Kuhn, Peter and Ian Wooton. INTERNATIONAL FACTOR MOVEMENTS IN THE PRESENCE OF A FIXED FACTOR.

8505C Nong, Kar-yju. GAINS FROM GOODS TRADE AND FACTOR MOBILITY.

8506C Weller, Paul and Makoto Yano. FUTURES MARKETS, REAL INCOME, AND SPOT PRICE VARIABILITY: A GENERAL EỌUILIBRIUM APPROACH.

8507C Dlewert, H.E. THE ETFECTS OF AN INNOVATION: A TRADE THEORY APPROACH.

8508C Ethier, Wilfred J. POREIGN DIRECT INVESTMENT AND THE MULTINATIONAL FIRM.

8509C Dinopoulos, Elias. INSIDE THE BLACK BOX: (IN)TANGIBLE ASSETS, INTRA-INDUSTRY INVESTMENT AND TRADE.

8510C Jones, Rlchard, John Whalley, and Randall H1gle. REGIONAL IMPACTS OF TARIFFS IN CANADA: PRELIMINARY RESULTS FROM A SMALL DIMENSIONAL NUMERICAL GENERAL EOUUIL IBRIUM MODEL.

8511C Whalley, John. HIDDEN CHALLENGES IN RECENT APPLIED GENERAL EQUIL IBRIUM EXERCISES.

8512C Smith, Bruce. SOME COLONIAL EVIDENCE ON TWO THEORIES OF MONEY: MARYLAND AND THE CAROLINAS.

9513C Grossman, S.J., A. Melino, and R.J. Sh1ller. ESTIMATING THE CONTINUOUS TIME CONSUMPTION BASED ASSET PRICING MODEL.

8514C Romer, Paul R. TAX EFFECTS AND TRANSACTION COSTS FOR SHORT TERM MARKET DISCOUNT BONDS.

8515C McCallum, Bennett T. ON CONSEỌUENCES AND CRITICISMS OF MONETARY TARGETING.

8516C Dinopoulos, Ellas and Ian Wooton. A NORTH-SOUTH MODEL OF INTERNATIONAL JUSTICE.

8517C Huffman, Gregory W. A DYNAMIC EQUILIBRIUM MODEL OF ASSET PRICES AND TRANSACTION VOLUME.

8518C Huffman, Gregory W. AN ALTERNATIVE VIEW OF OPTIMAL SEIGNIORAGE.

8519C Huffman, Gregory W. ASSET PRICING WITH HETERGENEOUS ASSETS. 
8520C Hercowitz, Zvi. THE REAL INTEREST RATE AND AGGREGATE SUPPLY.

8521C Davies, James and Michael Hoy. COMPARING INCOME DISTRIBUTIONS UNDER AVERSION TO DOWNSIDE INEQUALITY.

8522C Nguyen, Trien $T$. and John Whalley. COEXISTENCE OF EQUILIBRIA ON BLACK AND WHITE MARKETS.

8523C Clarete, Ramon and John Whalley. INTERACTIONS BETWEEN TRADE POLICIES AND DOMESTIC DISTORTIONS: THE PHILIPPINE CASE.

8524C Hamilton, Bob, Sharif Mohammad, and John Whalley. APPLIED GENERAL EQUILIBRIUM ANALYSIS AND PERSPECTIVES ON GROWTH PERFORMANCE.

8525C Huf fman, Gregory $W$. THE LAGGED EFFECTS OF POLICY ON THE PRICE LEVEL.

8526C Laldler, David. FISCAL DEFICITS AND INTERNATIONAL MONETARY INSTITUTIONS.

8527C Goodfriend, Marvin. MONETARY MYSTIQUE: SECRECY AND CENTRAL BANKING.

8528C Nguyen, Trien $T$. and John Whalley. GENERAL EQUILIBRIUM ANALYSIS OF PRICE CONTROLS A TWO-SECTOR COMPUTATIONAL APPROACH.

$8529 \mathrm{C}$ Heckman, James $\mathrm{J}$. and $\mathrm{V}$. Joseph Hotz. AN INVESTIGATION OF THE LABOR MARKET EARNINGS OF PANAMANIAN MALES: EVALUATING SOURCES OF INEQUALITY.

8530C Greenwood, Jeremy and Gregory W. Huffman. A DYNAMIC EQUILIBRIUM MODEL OF INFLATION AND UNEMPLOYMENT.

8531C Freeman, Scott. INSIDE MONEY, MONETARY CONTRACTIONS, AND WELFARE.

8532C Paderanga, Cayetano Jr. and Ian Wooton. A POSITIVE VIEW OF INFANT INDUSTRIES.

$8533 \mathrm{C}$ St-Hilaire, France and John Whalley. A MICROCONSISTENT DATA SET FOR CANADA FOR USE IN REGIONAL GENERAL EQUILIBRIUM POLICY ANALYSIS.

8534C Whalley, John. OPERATIONALIZING WALRAS: EXPERIENCE WITH RECENT APPLIED GENERAL EQUILIBRIUM TAX MODELS.

8535C Melvin, James R. THE GENERAL NON-EQUIVALENCE OF TARIFFS AND IMPORT QUOTAS. 
8601C Greenwood, Jeremy and R. Preston McAfee. EXTERNALITIES AND ASYMRETRIC INFORMATION.

8602C Dinopoulos, Elias and Mordecha1 E. Krelnin. IMPORT QUUOTAS AND VERS: A COMPARATIVE ANALYSIS IN A THREE-COUNTRY FRAMEWORK.

$8603 \mathrm{C}$ Clarete, Ramon and John Whalley. COMPARING THE MARGINAL WELFARE COSTS OF COMMODITY AND TRADE TAXES.

8604C Wigle, Randy. CANADIAN TRADE LIBERALIZATION: SCALE ECONOMIES IN A GLOBAL CONTEXT.

8605C Parkin, Michael. DOMESTIC MONETARY INSTITUTIONS AND FISCAL DEFICITS.

8606C Dinopoulos, Elias and Ian Wooton. INTERNATIONAL TRADE AND THE ACQUISITION OF SKILLS.

8607C Kawasaki, Seilchi and John McMillan. THE DESIGN OF CONTRACTS: EVIDENCE FROM JAPANESE SUBCONTRACTING.

8608C Williamson, Stephen D. LIQUIDITY, BANKING, AND BANK FAILURES.

8609C Grossman, Gene M. and Carl Shapiro. COUNTERFEIT-PRODUCT TRADE.

8610C Deardorff, Alan V. WHY DO GOVERNMENTS PREFER NONTARIFF BARRIERS?

$8611 \mathrm{C}$ Horstmann, Ignatius and James R. Markusen. LICENS ING VERSUS DIRECT INVESTMENT: A MODEL OF INTERNALIZATION BY THE MULTINATIONAL ENTERPRISE. 